\title{
Research on Improving the System of Ecological Civilization System
}

\author{
Yuanqiao Wang, Yuan Wang \\ School of Jilin Agricultural University, Changchun 13000, China
}

Keywords: Ecological Civilization, System Construction.

\begin{abstract}
The 18th National Congress of the Communist Party of China proposed that "strengthen the construction of ecological civilization system", the third plenary session of the 18th central committee has further proposed that "the construction of ecological civilization must establish a systematic system of ecological civilization system and protect the ecological environment with the system". Perfecting the system of ecological civilization system is an urgent task of contemporary Chinese ecological civilization construction, which has become the focus and hotspot of the current ecological research. The current system of ecological civilization in China still has some shortcomings and needs to be perfected. By analyzing economic, political, cultural and social issues related to ecologically, and put forward the corresponding countermeasures, which make them connect and adapt with each other, and enhance the understanding of the problem.
\end{abstract}

\section{The Basic Function of the Construction of Ecological Civilization System}

The 18th national congress of the communist party of China has incorporated ecological and cultural development into the overall layout of the "the overall plan for promoting all-round economic, political, cultural, social, and ecological progress "of socialism with Chinese characteristics. At the third plenary session of the 18th central committee of the Party has further proposed that the concept of "ecological civilization system", emphasis on the construction of ecological civilization must rely on the system of perfect ecological civilization system and system construction as the basic idea and guarantee of building ecological civilization. The ecological civilization system is an important part of our system, and Jinping Xi repeatedly stressed that "Only by implementing the most stringent system and the most rigorous rule of law can we provide reliable guarantee for the construction of ecological civilization". ${ }^{[1]}$

System is required to comply with the common rules of conduct or action, which plays an important role in the development and progress of human society. Because of the status and function of institutions in human society, "protection of the ecological environment must rely on the system, relying on the rule of law." [2] The construction of ecological civilization is the inner requirement of realizing Chinese dream, which is the common aspiration of the people of all nationalities. In order to build ecological civilization, we must deal with and coordinate a variety of complex social interests. And this requires the establishment of a comprehensive system, to guide and norms the complex relationship between the social interests. The third plenary session of the 18th central committee of the Party proposed that "Closely around the construction of beautiful China, deepen the reform of ecological civilization system, speed up the establishment of ecological civilization system." [3] Therefore, the ecological environment is the basis of human survival and development, the environment is closely related to people's political, economic, cultural and social life. Making the development of human society better, we must establish a set of effective ecological system in the whole society, attaching great importance to the basic role of building the ecological civilization system, ensuring the realization of the ambitious goal of "beautiful China".

\section{The Existing Problems of Ecological Civilization System in China}

With the country's emphasis on ecological civilization, the construction of ecological civilization in China has made some achievements. However, the time is short, the construction of ecological civilization system is still in the stage of exploration, and there are still some problems in the process of building and perfecting the system of ecological civilization system. 


\subsection{The ecological market system has not yet been established}

Although our country has established and gradually improved the socialist market economic system, has not yet established with the concept of ecological civilization to match the socialist market economic system. The ecological socialist market system requires citizens using ecological rationality to think about the relationship between man and nature and to be able to make economic decisions, including the use of traditional market methods to promote the way of consumption and changes in economic production methods. ${ }^{[4]}$ But the price of our country's resources and ecological products is not matched. For example, companies do not face the value of natural resources, pricing natural resources at low prices, making the price of the product can not reflect the scarcity of natural resources, which in the production process rarely consider the ecological factors, and the companies did not calculate the damage of the ecological environment and repair costs in the price, finally did not make the ecological value of the product reflected in the sale of the process.

\subsection{The relevant legal system of ecological environment protection needs to be improved}

Since the founding of the People's Republic of China, China has formulated the Constitution, Criminal Law, General Principles of Civil Law and a series of basic laws. But in the constitution, there is no provision for the construction of ecological civilization. With the continuous development of society and economy, people pay more and more attention to the ecological environment; however, the Constitution still did not join the relevant content on the construction of ecological civilization, and lacks the importance of ecological civilization.

Environmental Protection Law take a dominant position in China's ecological protection legal system, but its legislative focus is still around the economic work, the importance of ecological civilization construction and sustainable development in the Environmental Protection Law has not been fully reflected. And in the Criminal Law, there is no clearly what kind of behavior can constitute an ecological crime.

\subsection{Citizens have a weak sense of ecological civilization}

In front of the construction of ecological civilization, every citizen should do their part, because of social and economic development is not perfect, the citizen's understanding of environmental protection is not very deep, ecological civilization consciousness is still very weak, ecological concept has not yet established in the majority of the people's lives. At present, there are few educational aspects of ecological civilization in China, and the system of ecological civilization education has not yet been established. The knowledge system and composition of ecological civilization system are also imperfect. In the news media and public opinion publicity there also have any supporting system to cooperate with the ecological civilization system construction publicity. In addition, some environmental organizations in society, which are the lack of environmentally conscious personnel to join in and the lack of funds, what leading to environmental protection organizations are not yet mature, so the role of leading construction of ecological civilization are not useful.

\section{The Countermeasures to Strengthening the Construction of Ecological Civilization System in China}

In the overall process of ecological civilization construction, the system construction is the core, is the key, is also the guarantee, which we need continue to explore and practice. Improve the construction of ecological civilization system, the first priority is to supplement the gaps in the construction of ecological civilization and reform the rules that do not match the needs of the practice according to the current situation in China.

\subsection{Improve the ecological market system}

An ecological problem in the final analysis is the contradiction between economic development and ecological and environmental protection, which requires us to speed up the improvement of the ecological socialist market system to coordinate the construction of ecological civilization and the relationship between economic developments. First, we should improve the property rights system for natural resources. Perfecting the property rights system for natural resources is the basis of the construction of ecological civilization system. The state must first clear the attribution of all natural resources, and enjoy the use of natural rights and interests, but also bear the legal responsibility of 
protect these natural resources. Second, we should improve the legal system of damage to the ecological environment compensation and damage to the responsibility of the ecological environment. Strengthening the awareness of producers to protect the environment, it is necessary to increase the illegal costs, improve the damage to the ecological environment of the legal system. In case of causing damage to the ecological environment, the country should according to the relevant laws to make units or individuals to bear the corresponding legal responsibility.

\subsection{Improve the environmental protection system}

Our country needs to improve the legal system of ecological and environmental protection law on the basis of existing laws and regulations, revise the natural resources protection law and pollution prevention and control law, such as Forest Law, Prairie Law, Water Pollution Control Law, Marine Environmental Protection Law, which according to the foundation of the environment on China's actual situation to change the ecological problems. Still focus on the Constitution, Criminal Law and other basic laws of our country, and the development of ecological civilization system related to environmental protection system, reflecting the importance of ecological civilization construction and binding. Between the part of the overlap and cross in legal system, the law should be integrated and modified. Each law must carefully consider, collate, analyze, and establish a legal trial period to assess the feasibility of the law.

\subsection{Improve the public participation system}

The construction of ecological civilization system cannot be separated from the active participation of the people; we should attach great importance to mobilize the enthusiasm and creativity of the people to protect the ecological environment, in order to create a good atmosphere for the establishment of an ecological civilization system. First, we should put the ecological civilization education into the school teaching. Make the ecological civilization thought integrate into the basic education, to achieve " affect the family by educating students, affect the family by the influence of students, affect the social by the influence of family, enhance the community's sense of resource awareness and conservation of resources, the responsibility to protect the environment. " Second, we should increase the awareness of the concept of ecological civilization. The government should use the media to publish the correct ecological ideas, and disclosure of some information about the environment in time, so that the public for the protection of environmental protection gave a force. Third, we must pay attention to the role of civil society organizations. We should strengthen the cooperation with civil environmental organizations, help its development and growth, and improve the influence of ecological civilization system.

\section{References}

[1].Jinping Xi. Adhere to the basic national policy of saving resources and protecting the environment, strive to a new era of socialist ecological civilization. People's Daily. 2013-05-25, (001).

[2].Literature research center of the CPC Central Committee. Jinping Xi 's Compilation of Comprehensive Reform. Central Party Literature Press, 2014, p. 104.

[3].Ling Meng. Research on the construction of Chinese ecological civilization system[D].Liaoning University, China,2014,p.19.

[4].Xiaoyan Sun, Dan Wang. Reflections on the Construction of Ecological Civilization System. Yunnan Journal of Socialist Institute. 2014 No.2, p.342-343.

[5]. Jinping Xi. Vigorously develop the circular economy, building a resource - saving and environment - friendly society. Manage the world. 2005 No.7, p.4. 